\title{
DLEU1 Gene
}

National Cancer Institute

\section{Source}

National Cancer Institute. DLEU1 Gene. NCI Thesaurus. Code C24341.

This gene is involved in tumor suppression pertaining to chronic lymphocytic leukemia. 